\title{
Role of Traditional Textile Hand Prints of Barmer in Employment Generation
}

\author{
Nidhi Vats \\ Home Science Department, Kurukshetra University, Kurukshetra,India
}

\begin{abstract}
India has a long tradition of textile especially hand woven and hand spun textiles. Textiles stand next to agriculture as an income generation activity for most of the rural population. India has been renowned for its printed cotton clothes since the $12^{\text {th }}$ Century and creative processes flourished as the fabric received royal patronage. Different styles of design have been evolved in difference part of Country and District Barmer in Rajasthan is famous for its bold and vibrant motifs know by the name of 'Barmer hand prints'. The colors mainly used in Barmer hand prints are red, blue and maroon and motifs are mainly floral and geometrical. Hand Block Printing is such an art which can be used for making every design, every piece of cloth unique and different from others, which could never be possible by using automated machinery wherein 100s of meters of fabric would come out in the same design and color. The present study was conducted to find out about the financial setup, employment pattern generated by traditional textile hand printing. A sample size of 40 units was selected randomly and study was carried out with the help of survey and observation method. Pre-testing was done with the help of $10 \%$ of the sample and then data collection was done after which raw data was coded, tabulated and statically analyzed. Study revealed that profession of printing was hereditary and carried out generation to generation from father to son. The units were Small scale units which did not require heavy investments and provide employment to many people. In Barmer hand printing units, the worker employed did not require higher qualification except skill and efficiency. Thus this traditional textile printing plays a vital role in providing employment at every level and to all age group people. In Barmer, women are also cooperating in maintaining and managing the units. Thus Barmer hand prints provides sustainable livelihood to many local families. It is the essence of India and the crafts that make India stand out in the world, one of the numerous arts and crafts that are slowly dyeing and so have to be renewed and brought back to life. The diversification of design in the handloom sector is the need of the hour.
\end{abstract}

Key Words: hand prints, Barmer, textile

\section{Introduction}

The beginning of the art of ornamenting textile fabric by the stamping or printing one of color design are usually assumed to have originated in the far east and India and China are known to have practiced Hand printing with block from their earliest civilization. From India it spread slowly westward, by land through Persia, Asia minor, until it finally reached Germany, France and England. India is considered to be the birth place of printing on cotton fabric. India perhaps has had the longest continuous history of decorating fabric with dyes. Since ancient times, man has been using blocks for decorating clothes. The beginning of block printing was equally hard to trace but it was believed to have originated in the middle ages in several monasteries in the lower district of Germany between the tenth and the fourteenth century. Evidence that printing with wooden block was practiced from very early times exists in the discovery of small wooden block found in Egypt from fourth century. The hand printing industry spread all over the India. The ones which follow the traditional techniques are found in desert belt e.g Jaipur, Pali, Chittorgarh, Mathdwara, Jodhpur, Jaiselmer, Barmer, sanganer, Bagru of Rajasthan aNorthwest state of India can be described as the land of most colorful dyed and printing textile of India.

Barmer is the second largest district of Rajasthan and specialized in its production of beautiful hand block printing designed bed sheet. The uniqueness of Barmer hand block printing lies in the use of only vegetables dyes is the oldest and generally considered as the most artistic, of all methods of printing textiles. It is a slow process and subtle gradations of tint and stipple, the fine sharp outlines, the clear-cut edges of the masses, and the absolutely invisible joining up of the repeats. The origin of Barmer block printing was Sindh (Pakistan). It is only four hundred year old. At the time of partition, the people settled in Barmer(Rajasthan), Gujrat and started block printing is different from the printing of other centers. It has its own advantages, patterns containing any number of colors and on any scale can be reproduced with ease and certainty. The Barmer region is the home of very talented artisans live in scattered desert villages specializing in wood block printing and other traditional arts. This printing is carried from centuries ago, when women got tired of their 
white, unembellished garments and began using their bangles dipped in color to pattern their garments. The carpenters noticed and started making designs on wood to do the same. Thus began the tradition of making hand blocks for printing on textiles. Blocks are made of seasoned teak wood by trained craftsmen. The underside of the block has the design hand carved on it by the block maker. Each block has a wooden handle and two to three cylindrical holes drilled into the block for free air passage and also to allow release of excess printing paste. At early time the natural dyes were used for printing in Barmer but the procedure was very slow and with passage of time, the printer started the use of chemical dyes. The appearance of the Finished cloths depends on many factors, including the condition of the used block and quality of its carving, how evenly the cloth is laid on the print table and the degree of accuracy with which the block is registered mashed to the neighboring unit of repeat in the pattern.

Units involved in the printing were small scale. The industry received a great boost with the establishment of the All India Handicrafts Board with the active encouragement of the state during the sixties to ninties and Rajasthan Small Scale Industry Corporation in Jaipur. Textile printing is design to produce in Textile material multicolored patterns rather than a single coloured. Textile printing enhance the intrinsic beauty of textile. This ornamentation of fabric can be achieved by at which printing is most popular and extensively used. Textile printing is both an art as well as science. By printing textile is meant fabric on which a pattern is produced subsequent to the weaving of cloth by the application of dye stuff. Printing required highly specialized equipments materials and knowledge and a lot of aesthetic ability in order to achieve the desire effect. Mainly Khatri Community's people are involved in Barmer hand painting these are migrated from Pakistan with a passage of time Barmer hand prints became fomous throughout the country. Now it has its unique place as 'Barmer Hand Prints'. Barmer hand block printing wholly depends upon the human labour. Before 1975; the work of Barmer went unnoticed. People used to do printing at their own with government aid, it gained popularity and during this period the sample of the hand printing textile went in foreign. The Small Scale Industries Department of Rajasthan helped these printers in various ways by which the productivity increased and quality improved gradually.

The present study was under taken at Barmer District .There were two types of printing unit at barmer that is cottage unit and small scale unit .The number of cottage unit was found by door to door survey in Barmer.

In Barmer main workers constituted around 74 percent of all workers, while 26 percent were marginal workers. Among the main workers, 72.4 percent were cultivators and 2.8 percent agricultural workers, thereby implying that work force dependent on agriculture stood at 75.2 percent. Household industry just had 2.7 percent main workers. The other workers, those in service sectors and construction etc. constituted 22.2 percent of all workers. These results are again reflective of work opportunities available in the district. If men do not have work, females would have less work.

\section{Locale of the study:}

\section{Methodology}

The present study was conducted on hand block printing of district Barmer.

\section{Selection of method:}

For the present study the method used for the investigation was the survey method; as it is one of the most important and commonly used techniques for data collection. Data was collected by personally administering the interview schedule through observation.

\section{Formation of the interview schedule:}

The schedule is a form containing questions which are to be filled by the investigator after getting the information from the informants. The interview schedule contain question with specific aim of seeking information with regard to different aspects of the study.

\section{Employees:}

\section{- Information regarding division of different section in unit:}

The results of the study indicate that all the units were divided in to three sections: washing section, printing section, drying section.

- Information regarding the number of employees in the unit:

It was found that mainly male employees were there, female gave full cooperation in the work from printing to dyeing. In each unit the workers were divided as washer, printer, and dyer. The number of washer varied from 2 to 4 . The number of printer varied between 3 to 10 and that of dyers varied between 2 to 5 .

- Information regarding the nature of the worker employed :

It was found that almost all the units have skilled and experienced worker whenever they need some guidance, the owner provide them. 


\section{Result and Discussion}

Distribution of the units according to the pattern of employment of workers.

\begin{tabular}{|c|l|c|c|}
\hline Sr. No. & Pattern of employment & F & \% \\
\hline 1 & On contract & $\cdots$ & $\cdots$ \\
\hline 2 & Regular basis & 7 & 18 \\
\hline 3 & Both & 33 & 82 \\
\hline
\end{tabular}

\section{F- Frequency \%-percentage}

The data in the above table reveals that about $82 \%$ employed workers in the unit are either on regular basis or on contract basis.

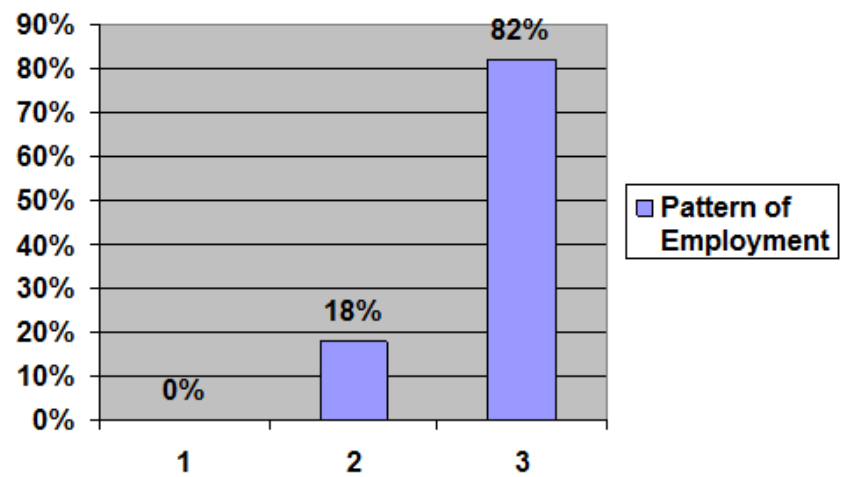

- Information regarding the training given to the workers:

By the survey, it was found that none of the unit provide any training to the workers.As the occupation was hereditary and whenever need arise, the owner provide help to the workers.

- Information regarding the working schedule of the workers:

Generally all the units worked in single shift, but during the time of heavy workloads, workers work over time.

- Information regarding the criteria of payment of wages to the workers:

All the units paid their payment on daily and piece basis. Daily wages were given to the dyers and washers. Printers were paid on piece basis.

\section{Distribution of units on the basis of wages given to the workers:}

\begin{tabular}{|c|l|c|c|}
\hline Sr. no. & Daily wages of works (Rs) & F & \% \\
\hline 1 & $70-80$ & 23 & 58 \\
\hline 2 & $80-90$ & 17 & 42 \\
\hline
\end{tabular}

\section{F- Frequency \%- percentage}

The data in the above table shows that the maximum number of units $(58 \%)$ paid daily wages to the worker in the range of 70-80 rupees followed by the 42 percent of the units which paid in the range of rupees $80-90$.

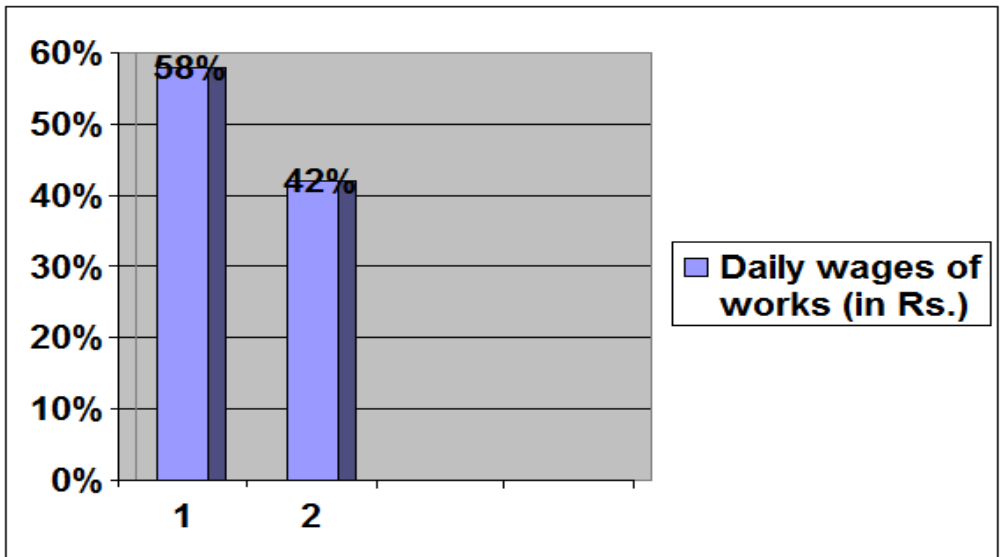




\section{Conclusion}

From this study it can be concluded that with passage of time awareness of the people towards the ethnic art of the country is increasing hence Barmer block printing is also becoming popular day by day. So due to demand in the market, units at both levels that is at cottage level and small scale level are increasing, which are providing employment opportunities to all.

\section{References}

[1]. S.R.Bajpai, Methods of Social Survey and Research. Kanpur Kitab Ghar. 1960.55,117.

[2]. J. Burnard, Chintz and Cotton: India's Textile Gift to the World, Kangaroo Press, Kenthurst, NSW 1994.

[3]. Chattopadhya, Kamakadevi. Indian Handicrafts. New Delhi: Indiam N Council of Culture Relations. 1985,.27-40.

[4]. Cooper, Ilay and John Gillow, 1996, Arts and Crafts of India, Thames and Hudson

[5]. P. H. Bhisham, Handicrafts of Rajasthan.Delhi:Director,Publication Division, Ministry of Information and Broadcasting, Government of India. 1984,.1-3.

[6]. V.Ramaswamy, Textiles and Weaver in Medieval S. India, Oxford Press, Delhi 1985,

[7]. Soni, Nandini, Block Printing of Bagru-A Historical Legend. 1999. 